\title{
Development of a legume-enriched feed for treatment of
}

\section{severe acute malnutrition [version 1; peer review: 1 approved,}

\section{1 approved with reservations]}

\author{
Kevin Walsh (1D1, Gael Delamare de la Villenaise de Chenevarin², Joe McGurk2, \\ Kathryn Maitland (D) $3,4^{*}$, Gary Frost (Di) ${ }^{*}$

\footnotetext{
${ }^{1}$ Section for Nutrition Research, Department of Medicine,, Imperial College London,, London, W12 ONN, UK 2Production and Processing Research Department, Campden BRI Group, Chipping Campden, GL55 6LD, UK

${ }^{3}$ Department of Infectious Disease and Institute of Global Health and Innovation, Division of Medicine, Imperial College London, London, W2 1PG, UK

${ }^{4}$ Clinical, KEMRI Wellcome Trust Research Programme, Kilifi, Kenya, PO Box 230, Kenya

${ }^{*}$ Equal contributors
}

V1 First published: 11 Aug 2021, 6:206
https://doi.org/10.12688/wellcomeopenres.16771.1

Latest published: 27 Jan 2023, 6:206

https://doi.org/10.12688/wellcomeopenres.16771.2

\section{Open Peer Review}

Approval Status

$?$

2

version 2

(revision)

27 Jan 2023

version 1

11 Aug 2021

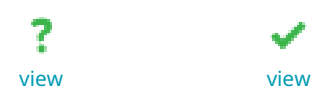

1. Sumathi Swaminathan (D), St John's

Research Institute, Koramangala, India

2. Paluku Bahwere, Free University of Brussels, Brussels, Belgium

Peter Akomo, Independent Consultant, Nairobi, Kenya

Any reports and responses or comments on the article can be found at the end of the article. 
are widely grown and eaten throughout Africa. Micronutrient content could not be matched in this ready-to-use product, so this was replaced at the point of feeding, as was fluid lost through concentration.

Conclusions: The processes and product described illustrate the development steps for a novel nutritional product. The new feed product was ready for evaluation for safety and efficacy in a phase II clinical trial in Ugandan children admitted to hospital with SAM (Modifying Intestinal MicroBiome with Legume-Based feed 2: MIMBLE feed 2 (ISRCTN10309022)).

Keywords severe acute malnutrition, undernutrition, legume, microbiome, ready-to-use therapeutic food, resistant starch

\section{KEMRI This article is included in the KEMRI | Wellcome \\ Trust gateway.}

Corresponding authors: Kathryn Maitland (k.maitland@imperial.ac.uk), Gary Frost (g.frost@imperial.ac.uk)

Author roles: Walsh K: Conceptualization, Investigation, Methodology, Writing - Original Draft Preparation, Writing - Review \& Editing; Delamare de la Villenaise de Chenevarin G: Methodology, Supervision, Validation, Writing - Review \& Editing; McGurk J: Methodology, Supervision, Validation, Writing - Review \& Editing; Maitland K: Conceptualization, Funding Acquisition, Methodology, Writing - Original Draft Preparation, Writing - Review \& Editing; Frost G: Conceptualization, Funding Acquisition, Methodology, Supervision, Writing Original Draft Preparation, Writing - Review \& Editing

Competing interests: No competing interests were disclosed.

Grant information: This work was supported by the Imperial College London Confidence in Concept scheme, which comprises of generous contributions from numerous sources including Imperial College Joint Translational Fund, MRC Confidence in Concept, EPSRC Impact Acceleration Account, NIHR Imperial Biomedical Research Centre Therapeutic Primer Fund, Rosetrees Trust, The Royal Marsden Hospital NHS Foundation Trust Fund, Wellcome Trust Institutional Strategic Support Fund, AstraZeneca, and Yuhan. Mbale Clinical Research Institute was supported by the Wellcome Trust [203077; KEMRI Wellcome Trust Programme East African Overseas Programme Award].

The funders had no role in study design, data collection and analysis, decision to publish, or preparation of the manuscript.

Copyright: (c) 2021 Walsh K et al. This is an open access article distributed under the terms of the Creative Commons Attribution License, which permits unrestricted use, distribution, and reproduction in any medium, provided the original work is properly cited.

How to cite this article: Walsh K, Delamare de la Villenaise de Chenevarin G, McGurk J et al. Development of a legume-enriched feed for treatment of severe acute malnutrition [version 1; peer review: 1 approved, 1 approved with reservations] Wellcome Open Research 2021, 6:206 https://doi.org/10.12688/wellcomeopenres.16771.1

First published: 11 Aug 2021, 6:206 https://doi.org/10.12688/wellcomeopenres.16771.1 


\section{Introduction}

It is estimated that $45 \%$ of all childhood mortality is due to undernutrition $^{1}$. Specifically, each year 1 million children's deaths can be attributed to undernutrition, the largest burdens being experienced in Southeast Asia and sub-Saharan Africa ${ }^{1}$. The World Health Organization (WHO) recommends milk-based feeds as the primary treatment for severe acute malnutrition (SAM), so-called F75 (starter) and F100 (catch up), whose names are based in their energy content (kilocalories/100mls). The recommended ingredients were first published by WHO in $1999^{2}$ and commercial formulations have also been developed (Nutriset, Malaunay, France). However, successful implementation requires prolonged hospitalisation or attendance to a feeding centre (for the child and their carer) as F100 prepared from non-sterile water or not stored correctly poses a high risk of bacterial contamination. To address the issues for famine situations in drought-ridden areas, with limited access to clean and safe water for reconstitution, ready-to-use therapeutic foods (RUTF) were developed by Valid International, equivalent to F100 in nutritional profile and containing peanuts, milk powder, sugar, oil and added mineral/vitamin $\mathrm{mix}^{3}$. Over the last decade these products have been widely used and have achieved impressive results in community-based therapeutic care (CTC) programmes ${ }^{4,5}$. Although a commercial product is available from Nutriset (Plumpynut) the hope was these recipes could be adapted for local manufacture and tested in field trials ${ }^{6}$.

Whilst there have been significant developments in CTC for children with SAM, children hospitalised with severe and complicated acute malnutrition continue to experience poor outcomes with inpatient mortality rates of $20 \%$, despite implementation of WHO guidelines ${ }^{7}$. Furthermore, longer term outcome remains poor with elevated rates of readmission and death occurring over the year after primary admission ${ }^{8}$. During admission and in the following year, many children die of infection-related complications ${ }^{8}$. Research to date has begun to identify several mechanisms that may partially account for the persistent high mortality including impaired gut barrier integrity, reduced mucosal immunity ${ }^{9}$ and increased risk of gram-negative bacteraemia ${ }^{10}$, increased nutrient requirements and losses (malabsorption), and altered gut microbial populations that favour pathogens ${ }^{11}$.

Diarrhoea affects a large proportion of fatal SAM cases ${ }^{10}$ with outcome substantially worse in those with diarrhoea (19\%) than those without $(9 \%)$. Bacteraemia appears to be the major risk factor for mortality in SAM cases complicated by diarrhoea ${ }^{10}$. A prospective study investigating associations between diarrhoea, enteropathogens, and markers of systemic and intestinal inflammation with mortality in Malawian children hospitalised with SAM found that high fecal calprotectin, low levels of fecal short-chain fatty acids (SCFAs) and markers of systemic inflammation were significantly associated with mortality ${ }^{12}$.

Current treatments and therapeutic feeds do not address all of these mechanisms and may exacerbate others. For example, the main carbohydrates in F75 and F100 are the disaccharides maltodextrin, sucrose and lactose, which are normally hydrolysed by brush border disaccharidases. However, intestinal atrophy ${ }^{13,14}$ and resultant functional lactase, maltase and sucrase deficiency ${ }^{15,16}$ have been demonstrated in SAM. High concentrations of undigested lactose in the intestinal lumen can result in osmotic diarrhoea, disrupting recovery ${ }^{17,18}$. Although much of this research predates the formulation of cow-milk based feed, in light of the emerging evidence of poor outcome a lactose-free formulation could improve outcomes in SAM, specifically in those who have or develop complicating diarrhoea ${ }^{10}$. While the nutritional profiles of F75 and F100 were not initially data-driven, the formulae have since been shown to support anthropometric recovery in uncomplicated SAM. The WHO guidelines outline a two-phased treatment: stabilisation and rehabilitation, with differing aims and approaches. In the initial stabilisation phase the main focus is on managing acute medical conditions, and cautious feeding ${ }^{2,19}$. The introduction of large amounts of carbohydrate in this stage may result in development of refeeding syndrome, so F75 (so called as it contains $0.75 \mathrm{kcal} / \mathrm{ml}$ ) formula contains only enough to support basic physiological function. Once the child is stabilised, the higher energy $\mathrm{F} 100$ formula $(1 \mathrm{kcal} / \mathrm{ml})$ is introduced to support weight gain.

It has been known for some time that the gut microbiota play a role in supporting the integrity of the gut barrier ${ }^{20}$. The principle mechanisms include direct competition with pathogens for nutrients and production of SCFA which have a number of favourable attributes. They can be used by intestinal epithelial cells as energy sources, but they also regulate intestinal $\mathrm{pH}$, modulate local gut immune reactivity, and produce bacteriocins $^{21,22}$. A landmark study in Malawi, showed that while F75 and F100 supported weight gain (the primary measure of successful 'nutritional' rehabilitation), the gut microbiota did not recover $^{23}$. Addition of fermentable carbohydrates (most commonly fructo- and galacto-oligosaccharides) to formula milks have been successful in increasing the concentrations of faecal Bifidobacteria and reducing stool $\mathrm{pH}$ in healthy children ${ }^{24}$. However, this has not been translated to the formulae used in children with SAM in low- and middle-income countries where case fatality remains a major problem.

We describe the development process of a lactose-free, fermentable carbohydrate-containing alternative to traditional F75 and F100 formulae for the treatment of SAM, for use in a phase II controlled clinical trial in Uganda: Modifying Intestinal MicroBiome using Legume-based feeds (MIMBLE II) ${ }^{25}$.

\section{Methods}

\section{Target nutritional profile}

For the novel feed developed here in April 2018 (Campden BRI, Chipping Campden, UK) it was decided to match the nutrient profile of F100 formula, so that with specific feeding protocols to match energy and carbohydrate provision in both phases, the feed could be used for both stabilisation and rehabilitation. In addition to the target nutritional profile, the current product was developed with two additional specifications as outlined above: to remove lactose as a disaccharide source and to ensure the final product had a resistant starch content of $0.4-0.5 \%$. 
WHO provides recipes for F75 and F100 formulae, so they can be produced with basic ingredients that are widely available, summarised along with nutrition profiles in Table 1. In developing the current feed, the principle that all components be widely and cheaply available was considered to be of utmost importance, as it is designed for use in Africa. Micronutrient concentration of the feed was matched to F75 and F100 as appropriate for the stage of treatment [2] by the provision of Therapeutic CMV (Nutriset, Fr) at the point of feeding.

\section{Nutritional profile determination}

The first steps were to concentrate the F100 formula $(1 \mathrm{kcal} / \mathrm{ml})$ by creating $4 \mathrm{kcal} / \mathrm{ml}$ (F400), $3 \mathrm{kcal} / \mathrm{ml}$ (F300) and $2 \mathrm{kcal} / \mathrm{ml}$ (F200) recipes to improve the transportability of the feed. Each recipe would be suitable for the proposed feeding protocol as a single pack could be opened and fed to multiple patients in varying amounts according to an age- and weight-appropriate

Table 1. Recommended composition of nutritional milks for children with severe malnutrition.

\begin{tabular}{|l|c|c|}
\hline Ingredient & F-75 (starter) & F-100 (catch up) \\
\hline Dried skimmed milk* & 25 & 80 \\
\hline Sugar (g) & 100 & 50 \\
\hline Vegetable oil (ml) & 35 & 70 \\
\hline Electrolyte/Mineral mix (ml) & 20 & 20 \\
\hline Water to make up & $1000 \mathrm{ml}$ & $1000 \mathrm{ml}$ \\
\hline Contents per 100ml & & \\
\hline Energy (kcal) & 75 & 100 \\
\hline Protein (g) & 0.9 & 2.9 \\
\hline Lactose (g) & 1.3 & 4.2 \\
\hline Sodium (mmol) & 0.6 & 1.9 \\
\hline Potassium (mmol) & 4.0 & 6.3 \\
\hline Magnesium (mmol) & 0.43 & 0.73 \\
\hline Zinc (mg) & 2.0 & 2.3 \\
\hline Copper (mg) & 0.25 & 0.25 \\
\hline \% energy from protein & 5 & 12 \\
\hline \% energy from fat & 36 & 53 \\
\hline Osmolarity (mOsmol/l) & 413 & 419 \\
\hline * alternative recipes which use full-cream & dried millk or liquid milk are: \\
\hline
\end{tabular}

F75: full-cream dried milk 35 g, $100 \mathrm{~g}$ sugar, $20 \mathrm{~g}$ (or ml) oil, $20 \mathrm{ml}$ electrolyte/ mineral solution, and make up to $1000 \mathrm{ml}$ or full-cream cow's milk (fresh or long-life) $300 \mathrm{ml}, 100 \mathrm{~g}$ sugar, $20 \mathrm{ml}$ oil, $20 \mathrm{ml}$ electrolyte/ mineral solution and make up to $1000 \mathrm{ml}$

F100: full-cream dried milk $110 \mathrm{~g}, 50 \mathrm{~g}$ sugar, $30 \mathrm{ml}$ oil, $20 \mathrm{ml}$ electrolyte/ mineral solution, and make up to $1000 \mathrm{ml}$ or full-cream cow's milk (fresh or long life) $880 \mathrm{ml}, 75 \mathrm{~g}$ sugar, $20 \mathrm{~g}$ (or ml) of oil, $20 \mathrm{ml}$ electrolyte/mineral solution and make up to $1000 \mathrm{ml}$ protocol. All nutritional targets for F100 were multiplied by two, three or four, respectively, for F200, F300, F400 and a recipe created to meet these targets. Nutritional content analysis was performed by Campden BRI, using United Kingdom Accreditation Service (UKAS) accredited methods for energy, fat, carbohydrate, fibre and protein. Resistant starch measurement was completed by Eurofins, following published methods ${ }^{26}$.

\section{Sourcing of ingredients, safety testing \& relevant legislation}

The risks and requirements that needed to be mitigated and met for each ingredient and finished product were conceptualised in 4 groups: nutritional, microbiological, physical and chemical (mycotoxins, heavy metals and pesticides). These were controlled through specifications at source by certificates of analysis (COA), but also with a supporting Hazard Analysis and Critical Control Point (HACCP) plan during process and then validated in a predetermined and detailed sampling plan in the finished product. The HACCP plan developed as per $\mathrm{Gaze}^{27}$ covered biological (pathogenic bacteria, yeasts and moulds), chemical (residues of auxiliary production substances, acrylamide, allergens) and physical (glass and glass like substances, hard plastic, metal, wood, pieces of packaging, stones) hazards from the receipt of the raw materials to despatch of the labelled products.

With respect to the regulations where legumes were absent or not specified, guidance for cereals was adopted. Heat treatment would have no impact on heavy metals/pesticides and these also need to be controlled at source. These standards were collated (Table 2) and ingredients were validated as above.

To meet the criteria set by Commission Regulation (EC) $2073 / 2005^{28}$ on microbiological criteria for foodstuffs, five cans of each production batch were subjected to a full sterility test following pre-incubation at $30^{\circ} \mathrm{C}$ for 14 days (similar to ambient storage conditions in Uganda), and an incubation on different culture media (Liver Broth, Dextrose Tryptone Broth, Plate Count Agar and Eugon agar plus 1\% Starch) at $25^{\circ} \mathrm{C}, 37^{\circ} \mathrm{C}$ and $55^{\circ} \mathrm{C}$ for a further 7 days. $\mathrm{pH}$ testing of final product performed by Campden BRI using United Kingdom Accreditation Service (UKAS) accredited $\mathrm{pH}$ meter inhouse method (TES-AC-223). Commission Regulation (EU) 2017/2158 ${ }^{29}$ establishes a benchmark level of acrylamide for baby foods of $40 \mu \mathrm{g} / \mathrm{kg}$. Benchmark levels are not maximum residue limits but effectively critical limits to determine the efficacy or inefficacy of the processing systems to mitigate acrylamide formation. Finally, as per Commission Regulation (EC) No $1881 / 2006^{30}$, the legume-based feed was tested for tin and lectin which respectively needed to be lower than $50 \mathrm{mg} / \mathrm{kg}$ and $400 \mathrm{HAU} / \mathrm{g}$. Acrylamide was analysed using liquid chromatography-tandem mass spectrometry (LC-MS/MS), lectin concentration by hemagglutination assay, and tin content by inductively coupled plasma - mass spectrometry (ICP-MS), all undertaken by Campden BRI (Chipping Campden, UK). Batch-by-batch results are summarised in the Extended data ${ }^{33}$. 
Table 2. Recipes and macro-nutrient profiles of concentrated feeds prior to retort and pre-gelatinisation.

\begin{tabular}{|c|c|c|c|c|c|c|}
\hline Ingredients (in $\mathrm{g} / \mathbf{1 0 0 g}$ ) & $\begin{array}{l}\text { Legume- } \\
\text { enriched } \\
\text { double } \\
\text { concentrated }\end{array}$ & & & & & \\
\hline Skimmed milk powder & 7.2 & & & & & \\
\hline Rapeseed oil & 11.5 & & & & & \\
\hline Gram flour & 10.0 & & & & & \\
\hline Sugar & 9.0 & & & & & \\
\hline Water & 62.3 & & & & & \\
\hline Nutritional content per $\mathbf{1 0 0 g}$ * & Target & $\begin{array}{l}\text { Pre-retort } \\
\text { batch }\end{array}$ & Batch 1 & Batch 2 & Batch 3 & Batch 4 \\
\hline Energy (kJ) & 837 & 846.1 & 816 & 808 & 795 & 770 \\
\hline Energy (kcal) & 200 & 203.2 & 195 & 193 & 190 & 184 \\
\hline Fat (g) & 12 & 12.1 & 12.1 & 12.0 & 11.1 & 11.9 \\
\hline of which saturates (g) & - & 0.9 & - & - & - & - \\
\hline Carbohydrates (g) & 18 & 18.1 & 18.1 & 18.2 & 19.1 & 15.6 \\
\hline of which sugars (g) & - & 12.0 & - & - & - & - \\
\hline Fibre, AOAC (g) & - & 0.9 & - & - & - & - \\
\hline Protein (g) & 5.6 & 5.6 & 5.8 & 5.9 & 5.9 & 5.3 \\
\hline Resistant starch (g) & $0.4-0.5$ & 0.09 & 0.4 & 0.4 & 0.3 & 0.3 \\
\hline Additional criteria** & Limit & & & & & \\
\hline Acrylamide ( $\mu \mathrm{g} / \mathrm{kg})$ & $(<40 \mu \mathrm{g} / \mathrm{kg})$ & NAt & 39 & 33 & 22 & 33 \\
\hline Lectin (HAU/g) & $(<400 \mathrm{HAU} / \mathrm{g})$ & $\mathrm{NA}^{\dagger}$ & $<40$ & $<40$ & $<40$ & $<40$ \\
\hline Tin (mg/kg) & $(<50 \mathrm{mg} / \mathrm{kg})$ & NA ${ }^{\dagger}$ & 0.02 & 0.01 & 0.02 & 0.01 \\
\hline Microbiological resultst† & Standard & & & & & \\
\hline $\mathrm{pH}($ mean $\pm \mathrm{SD})$ & - & NA & $5.65 \pm 0.03$ & $5.70 \pm 0.02$ & $5.70 \pm 0.03$ & $5.81 \pm 0.01$ \\
\hline Appearance (n/n acceptable) & Acceptable & NA & $5 / 5$ & $5 / 5$ & $5 / 5$ & $5 / 5$ \\
\hline Odour (n/n acceptable) & Acceptable & NA & $5 / 5$ & $5 / 5$ & $5 / 5$ & $5 / 5$ \\
\hline Microscopy (n/n negative) & Negative & NA & $5 / 5$ & $5 / 5$ & $5 / 5$ & $5 / 5$ \\
\hline Cultures at $25^{\circ} \mathrm{C}$ (n/n no growth) & No growth & NA & $5 / 5$ & $5 / 5$ & $5 / 5$ & $5 / 5$ \\
\hline Cultures at $37^{\circ} \mathrm{C}$ (n/n no growth) & No growth & NA & $5 / 5$ & $5 / 5$ & $5 / 5$ & $5 / 5$ \\
\hline Cultures at $55^{\circ} \mathrm{C}$ (n/n no growth) & No growth & NA & $5 / 5$ & $5 / 5$ & $5 / 5$ & $5 / 5$ \\
\hline
\end{tabular}

Abbreviations: AOAC, Association of Official Agricultural Chemists; HAU, hemagglutinin units; SD, standard deviation

* Nutritional content analysis was performed on 1 can per batch, resistant starch analysed in 2 cans per batch

** Acrylamide, lectin and tin testing completed for 1 can per batch

†Acrylamide, lectin and tin not assessed in trial, pre-retort batch

t† microbiological safety testing was conducted on $1 \%(5 / 500)$ cans per batch, but not on the pre-retort batch as it was not intended for use 
Processing of ingredients, testing of processes and final processing pathway

After homogenising the dry ingredients in a Giusti Vesuvio cook/cool system, the oil and water were incorporated, and an oil-in-water emulsion created. Cans with standard Epoxy lacquer $(73 \mathrm{~mm} \times 62 \mathrm{~mm}$, from PromoCan Ltd) were filled with the feed using a can depositor to a fill weight of approximately $205 \mathrm{~g}$ and seamed prior to retorting (Carnaud metalbox MB6 can seamer, Bead vertical 3 crate retort). One container was used for measurement of heat penetration and this was located in the centre of each layer in the retort to control the temperature and ensure that the cans had been processed at $121.1^{\circ} \mathrm{C}$ to achieve a $\mathrm{F}=20$ minutes. The canned feed then had to be processed in the retort within two hours after its temperature had fallen below $63^{\circ} \mathrm{C}$ to prevent the growth of microorganisms.

\section{Results}

Ingredient contaminant testing

Table 3 presents the results of contaminant testing of the ingredients, namely rapeseed oil, chickpea flour and lactose-free skimmed milk powder. In short, all parameters met the previously outlined criteria for each ingredient for metals, pesticide

Table 3. Chemical contaminants specifications for the ingredients.

\begin{tabular}{|c|c|c|c|}
\hline & Criteria & Requirement & Result \\
\hline \multirow[t]{7}{*}{ Rapeseed oil } & Lead & $0.1 \mathrm{mg} / \mathrm{kg}$ (wet weight) & $<0.005 \mathrm{mg} / \mathrm{kg}$ \\
\hline & Sum of dioxins (WHO-PCDD/F-TEQ) & $0.75 \mathrm{pg} / \mathrm{g}$ fat & $0.106 \mathrm{pg} / \mathrm{g}$ \\
\hline & Sum of dioxins and dioxin-like (WHO-PCDD/F-TEQ) & $1.25 \mathrm{pg} / \mathrm{g}$ fat & $0.116 \mathrm{pg} / \mathrm{g}$ \\
\hline & $\begin{array}{l}\text { Sum of PCB28, PCB52, PCB101, PCB138, PCB153 and } \\
\text { PCB180 (ICES - 6) }\end{array}$ & $40 \mathrm{ng} / \mathrm{g}$ fat & $0.0404 \mathrm{ng} / \mathrm{g}$ \\
\hline & Benzo(a)pyrene & $2.0 \mu \mathrm{g} / \mathrm{kg}$ & $0.809 \mu \mathrm{g} / \mathrm{kg}$ \\
\hline & $\begin{array}{l}\text { Sum of benzo(a)pyrene, benz(a)anthracene, } \\
\text { benzo(b)fluoranthene and chrysene }\end{array}$ & $10.0 \mu \mathrm{g} / \mathrm{kg}$ & $4.414 \mu \mathrm{g} / \mathrm{kg}$ \\
\hline & Erucic acid & $50 \mathrm{~g} / \mathrm{kg}$ & $4 \mathrm{~g} / \mathrm{kg}$ \\
\hline \multirow[t]{6}{*}{ Chickpea flour } & Lead & 0.2 mg/kg (wet weight) & $<0.005 \mathrm{mg} / \mathrm{kg}$ \\
\hline & Cadmium & $0.05 \mathrm{mg} / \mathrm{kg}$ & $0.012 \mathrm{mg} / \mathrm{kg}$ \\
\hline & Aflatoxin B1 & $2.0 \mu \mathrm{g} / \mathrm{kg}$ & $<1.0 \mu \mathrm{g} / \mathrm{kg}$ \\
\hline & Aflatoxins B1, B2, G1, G2 & $4.0 \mu \mathrm{g} / \mathrm{kg}$ & $<1.0 \mu \mathrm{g} / \mathrm{kg}$ \\
\hline & Ochratoxin A & $3.0 \mu \mathrm{g} / \mathrm{kg}$ & $<1.0 \mu \mathrm{g} / \mathrm{kg}$ \\
\hline & Pesticide residues & $\begin{array}{l}\text { Any } \\
\text { Haloxyfop }<0.15 \mathrm{mg} / \mathrm{kg}\end{array}$ & $\begin{array}{l}\text { Haloxyfop only } \\
0.04 \mathrm{mg} / \mathrm{kg}\end{array}$ \\
\hline \multirow{10}{*}{$\begin{array}{l}\text { Lactose-free skimmed } \\
\text { milk powder }\end{array}$} & Aflatoxin M1 & $0.05 \mu \mathrm{g} / \mathrm{kg}$ & $<0.03 \mu \mathrm{g} / \mathrm{kg}$ \\
\hline & Lead & $0.1 \mathrm{mg} / \mathrm{kg}$ (wet weight) & $0.02 \mathrm{mg} / \mathrm{kg}$ \\
\hline & Sum of dioxins (WHO-PCDD/F-TEQ) & $2.5 \mathrm{pg} / \mathrm{g}$ fat & $0.0253 \mathrm{pg} / \mathrm{g}$ \\
\hline & Sum of dioxins and dioxin-like PCBS (WHO-PCDD/F-PCB-TEQ) & $5.5 \mathrm{pg} / \mathrm{g}$ fat & $0.02759 \mathrm{pg} / \mathrm{g}$ \\
\hline & $\begin{array}{l}\text { Sum of PCB28, PCB52, PCB101, PCB138, PCB153 and } \\
\text { PCB180 (ICES - 6) }\end{array}$ & $40 \mathrm{ng} / \mathrm{g}$ fat & $0.0198 \mathrm{ng} / \mathrm{g}$ \\
\hline & Salmonella & absence in $25 \mathrm{~g}$ & Absent \\
\hline & Staphylococcal enterotoxins & absence in $25 \mathrm{~g}$ & Not detected \\
\hline & Enterobacteriaceae & 10 cfu/g (5 samples) & $<10 \mathrm{cfu} / \mathrm{g}$ \\
\hline & Coagulase positive staphylococci & $\begin{array}{l}10 \mathrm{cfu} / \mathrm{g} \text { ( } 5 \text { samples of which } \\
2 \text { allowed up to } 100 \mathrm{cfu} / \mathrm{g})\end{array}$ & $<10 c f u / g$ \\
\hline & Melamine & $\begin{array}{l}2.5 \mathrm{mg} / \mathrm{kg} \text { in food (except } \\
\text { powdered infant formulae) }\end{array}$ & $<0.05 \mathrm{mg} / \mathrm{kg}$ \\
\hline
\end{tabular}


residue, toxins and microbiological contamination. The COAs for ingredients demonstrated that the pesticides and heavy metals were within specification.

Table 2 also collates the specifications that need to be met for the ingredients with regard to chemical risks, as per COMMISSION REGULATION (EC) No 1881/2006 $6^{30}$, and associated test results from COAs or testing carried out by Campden BRI. Certificates of analysis (COA) for the chickpea from two reputable suppliers were screened for presence of pesticides which were quantified and compared to Regulation (EC) No $396 / 2005^{31}$ on maximum residue levels of pesticides in or on food and feed of plant and animal origin, and Directive (EC) No 125/2006 32 on processed cereal-based foods and baby foods for infants and young children. The Directive (EC) No $125 / 2006^{32}$ states that processed cereal based foods and baby foods must not contain residues of individual pesticides at levels exceeding $0.01 \mathrm{mg} / \mathrm{kg}$, except for substances for which more specific levels have been set in Annex VI of the regulation.

Relevant COAs for lactose-free skimmed and whole milk powders were available and from a due diligence point of view, the ingredient was checked for the absence of melamine. Early options explored the feasibility of a fat powder but due to alignment on product format, a vegetable oil was chosen. A rapeseed oil was sourced with all relevant documentation. The refined oil used in the manufacture of this product is automatically sterilised in the final processing stage. Moreover, the product's composition precludes the growth of pathogens, spoilage organisms and virtually all other micro-organisms. Similarly, crystalline sucrose (granulated sugar) was sourced from a reputable supplier with all necessary documentation. An in-house source of de-ionised water was used to standardise batches and have control over mineral addition.

\section{Nutrition, microbiological and other safety testing}

The final ingredients, target nutritional profile and nutritional, microbiological and final product safety testing results are presented in Table 3. Analyses on the raw cowpea flour revealed that it contained $0.9 \%$ of resistant starch which fell below the $3-4 \%$ expected, as reported in the literature ${ }^{33}$. At an incorporation level of $10 \%$ of the legume feed into the legume feed, the F200 formula would only provide $0.09 \%$ of resistant starch. As a result, roughly $88 \%$ of the recipe would have to comprise of the flour in order to meet the requirements if the resistant starch levels remained unchanged during processing. Of the final 2000 cans produced in 4 batches (each of $500 \times 200 \mathrm{~g}$ cans), each were deemed to meet the target nutritional profile, albeit with some batch-to-batch variation. Preretort, the product contained $0.09 \%$ resistant starch, increasing to $0.3-0.4 \%$ following retort, likely due to retrogradation. Energy content was slightly below the desired target of $837 \mathrm{~kJ} / 100 \mathrm{~g}$, ranging from $770-816 \mathrm{~kJ} / 100 \mathrm{~g}$. Concerning macronutrients, fat content was within $0.1 \mathrm{~g} / 100 \mathrm{~g}$ of the target $(12 \mathrm{~g} / 100 \mathrm{~g})$ in $3 / 4$ batches, while batch 3 contained $11.1 \mathrm{~g} / 100 \mathrm{~g}$. Carbohydrate content ranged from $15.6 \mathrm{~g} / 100 \mathrm{~g}$ to $19.1 \mathrm{~g} / 100 \mathrm{~g}$, with a target of $18 \mathrm{~g} / 100 \mathrm{~g}$. Protein showed similarly low variability, ranging from $5.3-5.9 \mathrm{~g} / 100 \mathrm{~g}$, with a target of $5.6 \mathrm{~g} / 100 \mathrm{~g}$.

Acrylamide was below the limit in all batches $(<40 \mu \mathrm{g} / \mathrm{kg})$, lectin concentration was below the detectable limits in all batches $(<40 \mathrm{HAU} / \mathrm{g})$, well below the limit of $<400 \mathrm{HAU} / \mathrm{g}$, and tin was similarly within the desired limit $(<50 \mathrm{mg} / \mathrm{kg})$ in all batches. Following incubation at $25^{\circ} \mathrm{C}, 37^{\circ} \mathrm{C}$ and $55^{\circ} \mathrm{C}$, of the 5 cans tested per batch, none were found to have any detectable growth of microorganisms, nor was there any observable organism with microscopy. Appearance and odour were both determined to be acceptable in all sampled cans. F200 achieved a $\mathrm{F}_{\mathrm{o}}=20$ after 55 minutes, whereas within this same time the F300 had only achieved a $F_{0}=7.62$.

\section{Discussion}

The development processes described above are summarised in Figure 1. This approach resulted in a safe and palatable product, which met the target nutritional characteristics of double concentrated F100 to address shortcomings in current feeds used to treat SAM. Selecting a single nutrient profile based on double-concentrated F100 (termed F200), which was adapted for use in stabilisation and rehabilitation phases, ensured simple product use on site, and reduced chance of providing the incorrect formula. The fluid lost through concentration was accounted for in the feeding protocol by provision of additional oral fluid to match standard treatment. Otherwise children who required treatment for dehydration would be managed as per WHO guidelines, i.e. through oral rehydration

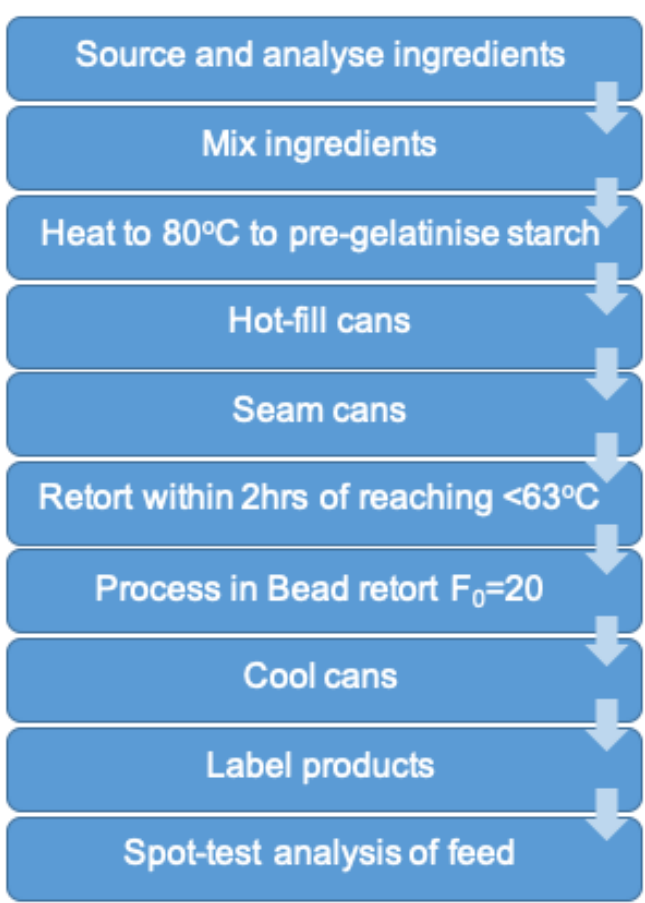

Figure 1. Final production process of legume-based feed. 
solution (ReSoMal) and/or intravenous rehydration using Ringer's lactate solution with 5\% glucose [2].

With regards to raw materials, out of all the required ingredients, the biggest risk was cowpea flour which would need to comply with levels permitted for contaminants in foodstuffs intended for infant consumption. Despite thorough searching, it was not possible to find a suitable source of cowpea flour, so chickpea (gram) flour was selected as an alternative and chickpeas are also a legume grown and eaten throughout Africa. Due to the complexity of the project it was decided not to process/mill the cowpeas on site and instead look to source in cowpea flour from a suitable supplier.

Despite the fact that 'safe' ingredients could be sourced, handling steps were unavoidable. A validation plan was created to extensively evaluate risks in the finished product. As not every product could be tested, a system allowing for a kill step and CCP (critical control point) at the end of any handling steps was adopted. Lectins and other anti-nutrients would need to be hydrolysed through heat treatment (e.g. retorting). Nevertheless, mycotoxins cannot be hydrolysed and must be prevented at the source. The feed could have taken the form of a dry mixed powder, later diluted and cooked in water; a low water activity fat-based paste which would have been sterilised; or a commercially sterilised product, where the organisms of concern would be controlled to a suitable level over the intended shelf life and storage conditions.

In the absence of aseptic production, which is not widely available in lower to middle income countries (LMICs), various risks needed to be extensively evaluated. Ready-to-use low water activity (Aw) fat pastes already exist (e.g. Plumpy'Nut ${ }^{\circledR}$ Nutriset, Paris) and could easily be created for this study. However, it could not be sterilised through heat treatment due to its low moisture content. A low Aw fat paste was therefore not a viable option. The standard formulae recommended by WHO, F75 and F100, are dry powders which are mixed and heated in water prior to consumption. But similar issues to low Aw fat pastes occurred with a powdered product format, with the additional risk of validating homogeneity. The choice was therefore in favour of a water-based paste which could be commercially sterilised.

It was recorded that during the process the texture of the feed after pre-gelatinisation of the starch was thicker before retorting than without pre-gelatinisation, and comparable to custard. After retorting, the texture was similar to mashed potatoes without sedimentation in the bottom of the cans which made it more homogeneous and suitable for a feeding trial (Figure 2). In terms of palatability, the legume-based feed had legume and caramel flavours. If the texture of the products F200, F300 and F400 was very suitable before retorting, the texture of F400 became hard after retorting and made it unsuitable for a feeding protocol using a syringe. In contrast, the F300 and F200 retained adequate paste-like consistency, suitable for use. However, due to the difference in viscosity, the products heating behaviour was different. The F300 heated most likely via conduction and a lot slower than the F200 which heated via convection. Overall, due to shorter processing time and better viscosity, F200 was the most feasible. Another issue was that the feed formed a thick sediment in the bottom of the cans which made the feed inhomogeneous and unsuitable for a feeding trial. This issue was mitigated by heating the feed up to $80^{\circ} \mathrm{C}$ prior to filling in the sealed system with the vent closed to pre-gelatinise the starch and minimise the moisture loss.

Table 4 compares the macro- and micronutrient provision by standard feeds to the legume-enriched feed during stabilisation and rehabilitation phases, inclusive of additional fluid/micronutrient supplementation at the point of use for legumeenriched feed, showing close alignment. This demonstrates an equivalence in terms of nutrient provision, with the legumeenriched feed matching or exceeding the WHO-recommended feeds for macro- and micronutrient provision. Specific improvements include non-reliance on local sources of clean water, reduction of disaccharide content, and addition of significant resistant starch content to support gut microbial populations. Challenges encountered included difficulty matching the micronutrient profiles $\mathrm{F} 75 / \mathrm{F} 100$ in a ready-to-use product, which was ultimately addressed by correction at the point of feeding. Fluid intake also had to be specifically addressed in the final study protocol to account for fluid lost through concentration.

\section{Future investigation}

The safety and efficacy of the resultant product will be assessed in a phase II randomised controlled trial ${ }^{25}$. Briefly, the MIMBLE II trial is an open-label controlled trial in 160 Ugandan children with SAM, defined by mid-upper arm circumference $<11.5 \mathrm{~cm}$ and/or presence of kwashiorkor. The trial will be conducted Mbale Regional Referral Hospital nutritional rehabilitation unit. Children will be randomised on a $1: 1$ basis to the lactose-free, chickpea enriched feed containing $2 \mathrm{kcal} / \mathrm{ml}$, provided in quantities to match usual energy provision (experimental) or WHO standard treatment F75 $(0.75 \mathrm{kcal} / \mathrm{ml})$ and F100 $(1 \mathrm{kcal} / \mathrm{ml})$ feeds (control). The co-primary outcomes are change in MUAC at day 90 and survival to day 90. Secondary outcomes include moderate-to-good weight gain $(>5 \mathrm{~g} / \mathrm{kg} / \mathrm{day})$, the development or worsening of diarrhoea (>3 loose stools/day) and time to diarrhoea resolution; time to oedema resolution (if the child presents with kwashiorkor (oedematous malnutrition)) and changes in intestinal biomarkers from admission to day 28 (faecal calprotectin). Supportive physiological data (to demonstrate whether the feed strategy is positively impacting gut function and microbial diversity) will include percentage changes in relative populations of gut microbiota, changes in generation of short chain fatty acid changes in host and microbiota metabolic products. In addition to the main trial outcomes we will assess palatability and safety of the nutritional feed. 


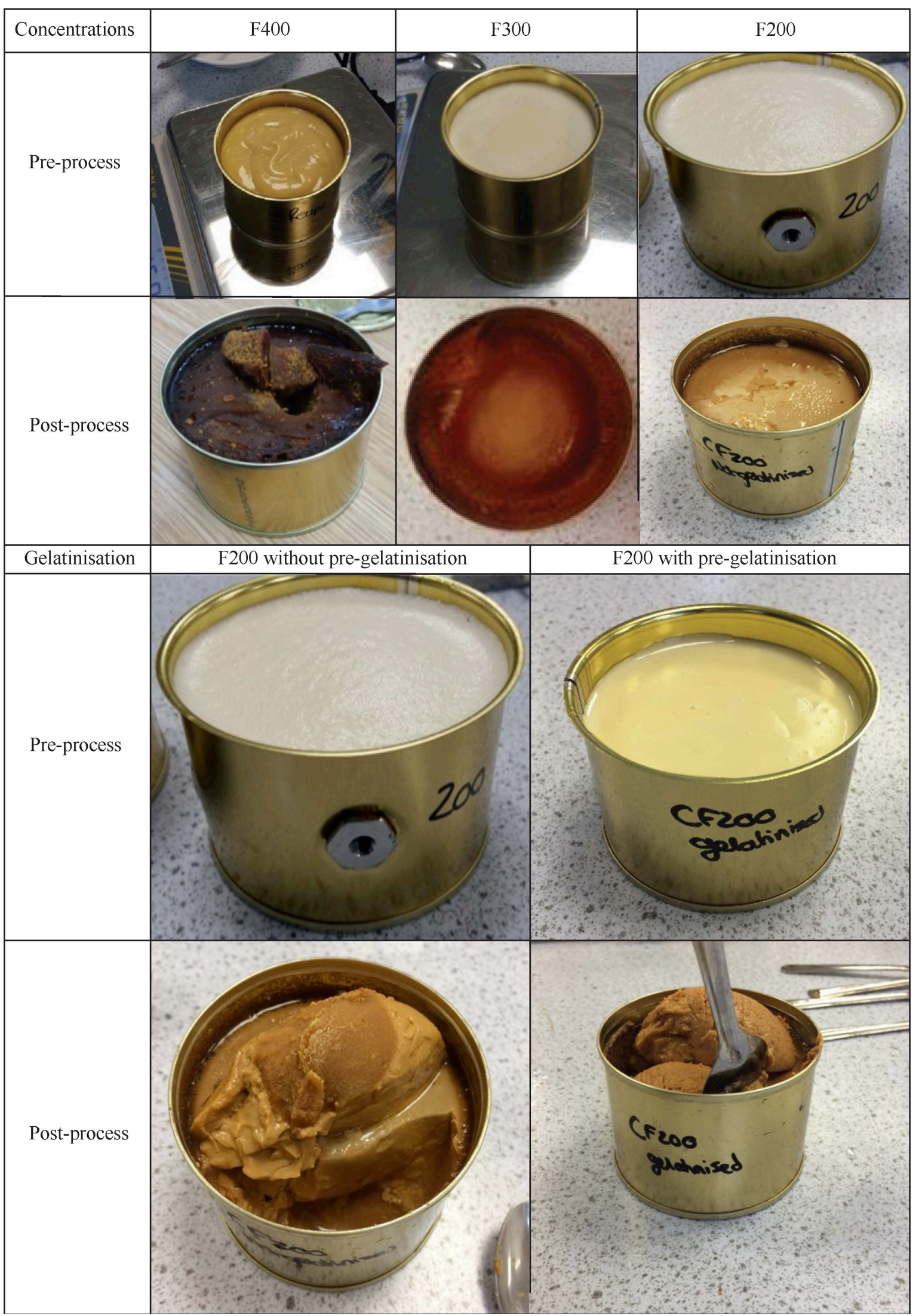

Figure 2. The effect of retort processing and pre-gelatinisation on texture of different feed concentrations. 
Table 4. Comparison of macronutrient and micronutrient provision during stabilisation and rehabilitation by standard feeds (F75/F100) and legume-enriched feed; data provided per kg of child weight per $24 \mathrm{hrs}$.

\begin{tabular}{|c|c|c|c|c|c|c|}
\hline & & \multicolumn{3}{|c|}{ Stabilisation Phase } & \multicolumn{2}{|c|}{ Rehabilitation Phase } \\
\hline & & Target[2] & F75 & Legume-enriched & F100 & Legume-enriched \\
\hline \multirow{3}{*}{ 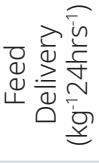 } & Feed amount in $24 \mathrm{hrs}$ & - & $135 \mathrm{ml}$ & $50 \mathrm{~g}$ & $150 \mathrm{ml}$ & $75 g$ \\
\hline & Additional Fluid (ml) & - & - & 100 & - & 105 \\
\hline & Therapeutic CMV (g) & - & - & 0.66 & - & 0.83 \\
\hline \multirow{8}{*}{ 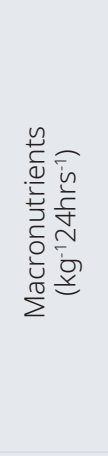 } & Fluid from feed (ml) & - & 135.0 & 131.1 & 150.0 & 151.7 \\
\hline & Energy (kcal) & 100 & 101.3 & 101.6 & 150.0 & 152.4 \\
\hline & Energy (kJ) & 420 & 425.3 & 426.7 & 630.0 & 640.1 \\
\hline & Protein (g) & $1-2 g$ & 1.2 & 2.8 & 4.4 & 4.2 \\
\hline & Fat (g) & - & 3.5 & 6.1 & 8.5 & 9.1 \\
\hline & Carbohydrate (g) & - & 16.9 & 9.0 & 14.3 & 13.5 \\
\hline & Lactose (g) & - & 1.8 & $<0.1$ & 6.3 & $<0.1$ \\
\hline & Resistant starch (g) & - & - & 0.2 & - & 0.2 \\
\hline \multirow{18}{*}{ 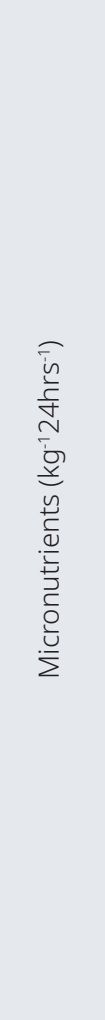 } & Potassium (mmol) & 4.00 & 4.86 & 6.78 & 8.85 & 10.17 \\
\hline & Sodium (mmol) & 1.00 & 0.81 & 0.82 & 2.85 & 1.23 \\
\hline & Magnesium (mmol) & 0.60 & 0.58 & 0.77 & 1.10 & 1.15 \\
\hline & Zinc $(\mu \mathrm{mol})$ & 30.00 & 50.63 & 64.19 & 54.00 & 96.29 \\
\hline & Copper ( $\mu \mathrm{mol})$ & 4.50 & 5.83 & 9.89 & 7.20 & 14.84 \\
\hline & Vitamin A (RE mg) & 0.15 & 0.41 & 0.31 & 0.45 & 0.47 \\
\hline & Thiamine (mg) & 0.07 & 0.11 & 0.15 & 0.14 & 0.22 \\
\hline & Riboflavin (mg) & 0.20 & 0.41 & 0.42 & 0.45 & 0.63 \\
\hline & Niacin (mg) & 1.00 & 1.15 & 2.10 & 1.43 & 3.15 \\
\hline & Pantothenic acid (mg) & 0.3 & 0.69 & 0.63 & 0.86 & 0.94 \\
\hline & Pyridoxine (mg) & 0.07 & 0.14 & 0.15 & 0.15 & 0.22 \\
\hline & Biotin (mg) & 0.01 & $<0.01$ & 0.02 & 0.02 & 0.03 \\
\hline & Folic acid $(\mu \mathrm{g})$ & 100.00 & 45.90 & 73.49 & 57.00 & 110.24 \\
\hline & Vitamin B12 ( $\mu \mathrm{g})$ & 0.10 & 0.41 & 0.21 & 0.45 & 0.31 \\
\hline & Vitamin C (mg) & 10.00 & 11.48 & 21.00 & 14.25 & 31.50 \\
\hline & Vitamin $\mathrm{D}(\mu \mathrm{g})$ & 3.00 & 6.62 & 6.30 & 8.55 & 9.45 \\
\hline & Vitamin E (mg) & 2.20 & 6.62 & 4.62 & 8.55 & 6.93 \\
\hline & Vitamin K ( $\mu \mathrm{g})$ & 4.00 & 11.07 & 8.40 & 14.25 & 12.60 \\
\hline
\end{tabular}

Abbreviations: RE, retinol equivalents

Based on the findings of this 160-patient trial we may require additional refinements to the feed composition and adaptation of the processing and manufacturing methods from this work, so that a lactose-free, prebiotic feed can be quickly and safely manufactured in any developing country. 


\section{Sponsor}

Imperial College London is the main research Sponsor for the MIMBLE II clinical trial that this feed was designed for. For further information regarding the sponsorship conditions, please contact the Head of Regulatory Compliance at:

Joint Research Office, Room 221b, Medical School Building, St Mary's Campus, Norfolk Place, London, W2 1PG. Telephone: +44 (0) 02075941872.

The sponsor and funder played no role in the feed design, manuscript preparation and the decision to submit the report for publication.

\section{Data availability}

Underlying data

Imperial College Research Data Repository: Supplemental File MIMBLE Feed analysis. https://doi.org/10.14469/hpc/8337 ${ }^{33}$.

Data are available under the terms of the Creative Commons Zero "No rights reserved" data waiver (CC0 1.0 Public domain dedication).

\section{Acknowledgements}

The study group would like to thank the children and families who have participated in the MIMBLE II trial for which this feed was designed to be assessed.
1. Black RE, Victora CG, Walker SP, et al.: Maternal and child undernutrition and overweight in low-income and middle-income countries. Lancet. 2013; 382(9890): 427-51.

PubMed Abstract | Publisher Full Text

2. Management of Severe Malnutrition: A manual for physicians and other senior health workers. Geneva: World Health Organization; 1999.

Reference Source

3. Collins S: Changing the way we address severe malnutrition during famine Lancet. 2001; 358(9280): 498-501.

PubMed Abstract | Publisher Full Text

4. Collins S: Community-based Therapeutic Care Approach. In: Khara T, Collins, S., editor. Community-based Therapeutic Care. 2004 Reference Source

5. Diop EHI, Dossou NI, Ndour MM, et al:: Comparison of the efficacy of a solid ready-to-use food and a liquid, milk-based diet for the rehabilitation of severely malnourished children: a randomized trial. Am J Clin Nutr. 2003; 78(2): 302-7.

PubMed Abstract | Publisher Full Text

6. Sandige $\mathrm{H}$, Ndekha MJ, Briend $\mathrm{A}$, et al: Home-based treatment of malnourished Malawian children with locally produced or imported readyto-use food. J Pediatr Gastroenterol Nutr. 2004; 39(2): 141-6. PubMed Abstract | Publisher Full Text

7. Maitland $\mathrm{K}$, Berkley JA, Shebbe $\mathrm{M}$, et al: Children with severe malnutrition: can those at highest risk of death be identified with the WHO protocol? PLoS Med. 2006; 3(12): e500.

PubMed Abstract | Publisher Full Text | Free Full Text

8. Berkley JA, Ngari M, Thitiri J, et al.: Daily co-trimoxazole prophylaxis to prevent mortality in children with complicated severe acute malnutrition: a multicentre, double-blind, randomised placebo-controlled trial. Lancet Glob Health. 2016; 4(7): e464-73.

PubMed Abstract | Publisher Full Text | Free Full Text

9. Bhutta ZA, Berkley JA, Bandsma RHJ, et al: Severe childhood malnutrition. Nat Rev Dis Primers. 2017: 3: 17067.

PubMed Abstract | Publisher Full Text | Free Full Text

10. Talbert A, Thuo N, Karisa J, et al.: Diarrhoea complicating severe acute malnutrition in Kenyan children: a prospective descriptive study of risk factors and outcome. PLoS One. 2012; 7(6): e38321. PubMed Abstract | Publisher Full Text | Free Full Text

11. Pham TP, Tidjani Alou M, Bachar D, et al:: Gut Microbiota Alteration is Characterized by a Proteobacteria and Fusobacteria Bloom in Kwashiorkor and a Bacteroidetes Paucity in Marasmus. Sci Rep. 2019; 9(1): 9084. PubMed Abstract | Publisher Full Text | Free Full Text

12. Attia S, Versloot CJ, Voskuijl W, et al.: Mortality in children with complicated severe acute malnutrition is related to intestinal and systemic inflammation: an observational cohort study. Am J Clin Nutr. 2016; 104(5): $1441-9$.

PubMed Abstract | Publisher Full Text | Free Full Text

13. Stanfield JP, Hutt MS, Tunnicliffe R: Intestinal biopsy in kwashiorkor. Lancet.
1965; 2(7411): 519-23

PubMed Abstract | Publisher Full Text

14. Schneider RE, Viteri FE: Morphological aspects of the duodenojejunal mucosa in protein--calorie malnourished children and during recovery. $A m$ J Clin Nutr. 1972; 25(10): 1092-102.

PubMed Abstract | Publisher Full Text

15. Prinsloo JG, Wittmann W, Kruger $\mathrm{H}$, et al.: Lactose absorption and mucosal disaccharidases in convalescent pellagra and kwashiorkor children. Arch Dis Child. 1971; 46(248): 474-8.

PubMed Abstract | Publisher Full Text | Free Full Text

16. James WP: Jejunal disaccharidase activities in children with marasmus and with kwashiorkor. Response to treatment. Arch Dis Child. 1971; 46(246): 218-20.

PubMed Abstract | Publisher Full Text | Free Full Text

17. Nyeko R, Kalyesubula I, Mworozi $\mathrm{E}$, et al.: Lactose intolerance among severely malnourished children with diarrhoea admitted to the nutrition unit Mulago hospital, Uganda. BMC Pediatr. 2010; 10: 31 PubMed Abstract | Publisher Full Text | Free Full Text

18. Prinsloo JG, Wittmann W, Pretorius PJ, et al.: Effect of different sugars on diarrhoea of acute kwashiorkor. Arch Dis Child. 1969; 44(237): 593-9. PubMed Abstract | Publisher Full Text | Free Full Text

19. World_Health_Organization: Updates on the management of severe acute malnutrition in infants and children. Geneva WHO; 2013. Reference Source

20. Ramakrishna BS: Role of the gut microbiota in human nutrition and metabolism. J Gastroenterol Hepatol. 2013; 28 Suppl 4: 9-17. PubMed Abstract | Publisher Full Text

21. Martin-Peláez S, Gibson GR, Martín-Orúe SM, et al.: In vitro fermentation of carbohydrates by porcine faecal inocula and their influence on Salmonella Typhimurium growth in batch culture systems. FEMS Microbiol Ecol. 2008; 66(3): 608-19.

PubMed Abstract | Publisher Full Text

22. Roberfroid M, Gibson GR, Hoyles L, et al.: Prebiotic effects: metabolic and health benefits. BrJ Nutr. 2010; 104 Suppl 2: S1-S63. PubMed Abstract | Publisher Full Text

23. Reyes A, Blanton LV, Cao S, et al.: Gut DNA viromes of Malawian twins discordant for severe acute malnutrition. Proc Natl Acad Sci U S A. 2015; 112(38): $11941-6$

PubMed Abstract | Publisher Full Text | Free Full Text

24. Vandenplas $Y$, De Greef E, Veereman G: Prebiotics in infant formula. Gut Microbes. 2014; 5(6): 681-7. PubMed Abstract | Publisher Full Text | Free Full Text

25. Walsh $\mathrm{K}$, Calder $\mathrm{N}$, Olupot-Olupot $\mathrm{P}$, et al.: Modifying Intestinal Integrity and Micro Biome in Severe Malnutrition with Legume-Based Feeds (MIMBLE 2.0): protocol for a phase II refined feed and intervention trial [version 1 ; peer review: 2 approved]. Wellcome Open Res. 2018; 3: 95 PubMed Abstract | Publisher Full Text | Free Full Text

26. McCleary BV, Monaghan DA: Measurement of Resistant Starch. J AOAC Int 
2002; 85(3): 665-75.

PubMed Abstract | Publisher Full Text

27. Gaze R: Guideline 42. HACCP: a practical guide (Fifth Edition). Gloucestershire, UK: Campden BRI; 2015 Reference Source

28. European Commission: Commission Regulation (EC) No 2073/2005 of 15 November 2005 on microbiological criteria for foodstuffs. Official Journal of the European Union. 2005; L338: 1-26. Reference Source

29. European Commission: Commission Regulation (EU) 2017/2158 of 20 November 2017 establishing mitigation measures and benchmark levels for the reduction of the presence of acrylamide in food. Official Journal of the European Union. 2017; L304: 22-44.

Reference Source

30. European Commission: Commission Regulation (EC) 1881/2006 of 19 December 2006 setting maximum levels for certain contaminants in foodstuff. Official Journal of the European Union. 2006; L364: 5-24. Reference Source

31. European Commission: B Regulation (EC) No 396/2005 on maximum residue levels of pesticides in or on food and feed of plant and animal origin. Official Journal of the European Union. 2005; L70: 1 Reference Source

32. European Commission: Commission Directive (EC) $2006 / 125$ on processed cereal-based foods and baby foods for infants and young children. Official Journal of the European Union. 2006; L339: 16-35. Journal of the Europ
Reference Source

33. Chung $\mathrm{HJ}$, Liu Q, Hoover R, et al.: In vitro starch digestibility, expected glycemic index, and thermal and pasting properties of flours from pea, lentil and chickpea cultivars. Food Chem. 2008; 111(2): 316-21. PubMed Abstract | Publisher Full Text

33. Maitland K: Supplemental File MIMBLE Feed analysis. Version 1. Imperial College London Data Repository. Dataset. 2021.

http://www.doi.org/10.14469/hpc/8337 


\section{Open Peer Review}

\section{Current Peer Review Status:}

\section{Version 1}

Reviewer Report 07 October 2021

https://doi.org/10.21956/wellcomeopenres.18496.r45474

(C) 2021 Bahwere $\mathbf{P}$ et al. This is an open access peer review report distributed under the terms of the Creative Commons Attribution License, which permits unrestricted use, distribution, and reproduction in any medium, provided the original work is properly cited.

\section{Paluku Bahwere}

Centre of Research in Epidemiology, Biostatistics and Clinical Research, School of Public Health, Free University of Brussels, Brussels, Belgium

\section{Peter Akomo}

Independent Consultant, Nairobi, Kenya

The project reported aims to develop an alternative formulation to F75 and F100 that according to the authors will be superior in reducing mortality through eliminating lactose in the food hence reducing risk of osmotic diarrhoea and will better promote the growth of "good" intestinal bacteria commensal flora. This makes scientific sense, and the research team has provided sufficient scientific information to back its hypothesis. Our main concern is the lack of information on the proportion of malnourished children who will benefit from the research products if the results are positive. In our opinion the research come in too late as currently over $90 \%$ of severely malnourished children accessing treatment are treated as outpatient. Also, life-threatening osmotic diarrhoea occurs only in a small proportion of children requiring inpatient stabilisation, except in few countries such us Zambia. Whereas complete removal of lactose from the formula could be achieved and can procure some health benefits, it might worth also recognising some importance of lactose in infant nutrition including some level of microbiota-modulating effect.

Some statements need to be corrected. The standard RUTF was not developed by Valid International. Also, F175 and F100 are not for treating uncomplicated SAM but for complicated SAM.

It will be helpful to provide more details on the calculation of the sample size of the follow up. We are not sure that a sample size of 160 will have sufficient power to demonstrate difference in mortality.

For programmatic use, changes in rheological characteristics during storage are important aspects to be sure about. There is no mention of studying this aspect. It might to be good to include this phase and provide data on effect of storage 
Information on the cost will be very important for the uptake of the novel feed. Including some cost information is important even if it is limited to ingredients cost.

Is the work clearly and accurately presented and does it cite the current literature? Yes

Is the study design appropriate and is the work technically sound?

Yes

Are sufficient details of methods and analysis provided to allow replication by others? Yes

If applicable, is the statistical analysis and its interpretation appropriate? Not applicable

Are all the source data underlying the results available to ensure full reproducibility? No source data required

Are the conclusions drawn adequately supported by the results? Yes

Competing Interests: No competing interests were disclosed.

Reviewer Expertise: Undernutrition

We confirm that we have read this submission and believe that we have an appropriate level of expertise to confirm that it is of an acceptable scientific standard.

Reviewer Report 25 August 2021

https://doi.org/10.21956/wellcomeopenres.18496.r45404

(C) 2021 Swaminathan S. This is an open access peer review report distributed under the terms of the Creative Commons Attribution License, which permits unrestricted use, distribution, and reproduction in any medium, provided the original work is properly cited.

\section{Sumathi Swaminathan}

Division of Nutrition, St John's Research Institute, Koramangala, Bangalore, India

The authors describe the process of development of a legume-based food product designed to improve the gut microbiome diversity and integrity and to reduce the rate of diarrhoea in hospitalized children with severe acute malnutrition. The results of this group's pilot clinical trial is reported in the journal Cell Reports (Calder et al., 2021). ${ }^{1}$

The description of the development of the formulation seems complicated with proper justification for the choice of ingredients and the type of analysis done not provided. The laboratory analysis seems to have been done for nutrients, microbial content, pesticide, 
environmental pollutants, heavy metals, and adulterants for only the individual ingredients and not the finished product. It appears that the shelf-life test was not done as it is not reported. A product's shelf life needs to be reported along with organoleptic and nutrient stability over a period along with absence of microbial growth.

The quality of protein has not been evaluated for this food product. This is an essential requirement in the development of a food product particularly in children with SAM. Specific comments on the manuscript are as follows: Introduction: The authors mention Southeast Asia and sub-Saharan Africa, when, it is Asia and sub-Saharan Africa. Please refer to UNICEF-WHO-The World Bank: Joint child malnutrition estimates - levels and trends - 2021 edition. The introduction needs can be more focussed beginning with the burden, the current solution, the reason development of the legume-based product giving a brief paragraph on diarrhoea, and the gut microbiome and the aim of the current study. Several sentences can be shifted to the discussion section.

The target nutritional profile section in the methods is difficult to comprehend. It mentions "match the nutrient profile of F100 formula, so that with specific feeding protocols to match energy and carbohydrate provision in both phases, the feed could be used for both stabilisation and rehabilitation". The meaning of this part of the sentence is not clear. Further, the next paragraph mentions that the micronutrient content was matched for F75 or F100. To add to the confusion, "Micronutrient concentration of the feed was matched to F75 and F100 as appropriate for the stage of treatment [2] by the provision of Therapeutic CMV (Nutriset, Fr) at the point of feeding. The meaning of this is again difficult to understand in the context of the previous section written. The authors need to justify the need to concentrate the F100 formula $(1 \mathrm{kcal} / \mathrm{ml})$ by creating $4 \mathrm{kcal} / \mathrm{ml}$ (F400), 3kcal/ml (F300) and $2 \mathrm{kcal} / \mathrm{ml}$ (F200) recipes. Presume this was done by differential addition of water. Or was this done by a different method?

In the section on Sourcing of ingredients, safety testing \& relevant legislation a lot of jargon has been used. The meaning of this statement "With respect to the regulations where legumes were absent or not specified, guidance for cereals was adopted" is not clear. The paragraph starting with "To meet the criteria set by Commission Regulation------ is undecipherable and its relevance is not clear.

A tin container seems to have been used. This cannot be cost-effective in a country like Uganda. If tin was used there can be traces of metals leaching into the food product. The tin content has been analysed for each batch and the content is low, but not done during a shelf-life test.

The composition of the food product includes rapeseed oil. This does not seem to be used in the Ugandan diet. The justification for the use of this oil, particularly as it contains erucic acid is required.

There is no clarity on the type of legume used, that is, whether it was finally cowpea or chickpea. The manuscript published in the journal Cell Reports mentions cowpea. So which legume was used?

Shelf-life studies need to be done before the product is used for a study. If it has been done it needs to be reported. The manuscript should then be modified once this is completed.

\section{References}

1. Calder N, Walsh $\mathrm{K}$, Olupot-Olupot $\mathrm{P}$, Ssenyondo $\mathrm{T}$, et al.: Modifying gut integrity and microbiome in children with severe acute malnutrition using legume-based feeds (MIMBLE): A pilot trial.Cell Rep Med. 2021; 2 (5): 100280 PubMed Abstract | Publisher Full Text

\section{Is the work clearly and accurately presented and does it cite the current literature?}


No

Is the study design appropriate and is the work technically sound?

Partly

Are sufficient details of methods and analysis provided to allow replication by others? Partly

If applicable, is the statistical analysis and its interpretation appropriate?

Not applicable

Are all the source data underlying the results available to ensure full reproducibility? No source data required

Are the conclusions drawn adequately supported by the results?

No

Competing Interests: No competing interests were disclosed.

Reviewer Expertise: Nutrition

I confirm that I have read this submission and believe that I have an appropriate level of expertise to confirm that it is of an acceptable scientific standard, however I have significant reservations, as outlined above.

\section{Comments on this article}

\section{Version 1}

\section{Author Response 16 Dec 2022}

Kathryn Maitland, Imperial College London, London, UK

We thank the reviewer for very details critique of our manuscript and we have edited the paper accordingly. Here we address each of the points the reviewer raises.

The authors describe the process of development of a legume-based food product designed to improve the gut microbiome diversity and integrity and to reduce the rate of diarrhoea in hospitalized children with severe acute malnutrition. The results of this group's pilot clinical trial is reported in the journal Cell Reports (Calder et al., 2021). ${ }^{1}$

Response: point of clarification - the reviewer has cited a pilot study which did not use the feed being described in the current manuscript.

Comment: The description of the development of the formulation seems complicated with proper 
justification for the choice of ingredients and the type of analysis done not provided. The laboratory analysis seems to have been done for nutrients, microbial content, pesticide, environmental pollutants, heavy metals, and adulterants for only the individual ingredients and not the finished product. It appears that the shelf-life test was not done as it is not reported.

Response: The analysis was done on the final batch ie the finished product and 5 tins were analysed. These are reported in the main text and in Table 2. In the method section we have added in more details on choice of ingredients. Comment: A product's shelf life needs to be reported along with organoleptic and nutrient stability over a period along with absence of microbial growth. Response: We agree that were this to be used more widely that shelf-life would need to be provided. However, the final product was contained in a sealed can and for use only in a clinical trial (over the next year).

Comment: The quality of protein has not been evaluated for this food product. This is an essential requirement in the development of a food product particularly in children with SAM.

Response: Once again we agree that were this to be a commercial product for widespread and longerterm use this would be essential. We justify not having taken this approach for the current trial for three reasons outlined below: 1. The primary protein source of the feed is the same as that recommended by WHO (skimmed-milk powder) 2. Dairy protein has already been shown to have high protein quality scores (Manary et al., 2016. Food and Nutr Bull; 37:1 supp. S29-S26) to meet the specific needs of the target population, children with SAM 3. The total protein concentration exceeded the target concentration, i.e. equivalent to WHO F-100 feed, in all but one batch. Despite this in Table 4 we show that in the stabilisation phase we provide more high quality protein than F-75 (2.8g/kg/24hrs vs. $1.2 \mathrm{~g} / \mathrm{kg} / 24 \mathrm{hrs})$, and almost equivalent amounts in the rehabilitation phase compared to F-100 (4.2g/kg/24hrs vs $4.4 \mathrm{~g} / \mathrm{kg} / 24 \mathrm{hrs}$ )

Specific comments on the manuscript are as follows:

Comment: Introduction: The authors mention Southeast Asia and sub-Saharan Africa, when, it is Asia and sub-Saharan Africa. Please refer to UNICEF-WHO-The World Bank: Joint child malnutrition estimates - levels and trends - 2021 edition. The introduction needs can be more focussed beginning with the burden, the current solution, the reason development of the legume-based product giving a brief paragraph on diarrhoea, and the gut microbiome and the aim of the current study. Several sentences can be shifted to the discussion section.

Response: We have followed the reviewers'suggestions - please see tracked changes. In the introduction the current recommendations are followed by the current outcomes (and specific high risk groups are well covered) followed by our solution. We have moved the section on community-based care to the discussion.

Comment: The target nutritional profile section in the methods is difficult to comprehend. It mentions "match the nutrient profile of F100 formula, so that with specific feeding protocols to match energy and carbohydrate provision in both phases, the feed could be used for both stabilisation and rehabilitation". The meaning of this part of the sentence is not clear. Further, the next paragraph mentions that the micronutrient content was matched for F75 or F100. To add to the confusion, "Micronutrient concentration of the feed was matched to F75 and F100 as 
appropriate for the stage of treatment [2] by the provision of Therapeutic CMV (Nutriset, Fr) at the point of feeding. The meaning of this is again difficult to understand in the context of the previous section written.

Response: We have tried to make the text clearer. In summary, while a single formula macronutrient profile was developed, this could be adapted to both stabilisation and rehabilitation phases by feeding different quantities to children in each phase. Micronutrient supplementation was added not during manufacture but at the point of feeding, also to allow use to add different amounts to match the WHOrecommended feeding approaches for each phase. We believe that Table 4 and the preceding text clearly show how the feed, as taken by children, meets the reference feeds F-75/F-100.

Comment: The authors need to justify the need to concentrate the F100 formula $(1 \mathrm{kcal} / \mathrm{ml})$ by creating $4 \mathrm{kcal} / \mathrm{ml}$ (F400), 3kcal/ml (F300) and $2 \mathrm{kcal} / \mathrm{ml}$ (F200) recipes. Presume this was done by differential addition of water. Or was this done by a different method?

Response We have made this clearer in the text why we did this and added on more details about how the final feed was administered. In the SOP we had a detailed description for the clinical teams on how to dilute the concentrate for each of the stabilisation (F75 equivalent) and nutritional phase (F100 equivalent).

Comment: In the section on Sourcing of ingredients, safety testing \& relevant legislation a lot of jargon has been used. The meaning of this statement "With respect to the regulations where legumes were absent or not specified, guidance for cereals was adopted" is not clear. The paragraph starting with "To meet the criteria set by Commission Regulation------ is undecipherable and its relevance is not clear.

Response Thank you for pointing this out. We have amended the sentences to make it clearer. Moreover we would like to note that there are no standards for legumes within baby feed since we are opting for a novel approach and this is not covered in current baby food regulations.

Comment: A tin container seems to have been used. This cannot be cost-effective in a country like Uganda. If tin was used there can be traces of metals leaching into the food product. The tin content has been analysed for each batch and the content is low, but not done during a shelf-life test.

Response: As we pointed out previously this was a point of principal study where we designed the feed only for this study. The company explored various ways in which to generate and store a feed that had eventually undergo a heat procedure to ensure the microbiological safety. The only safe way that it could be done with technology available to them at the time (and within the budget available) was to package it in a tin. For the European market they have made other products using the tin methods which is specifically coated so the metal can cannot contaminate the product within it. This is noted in the method "standard epoxy lacquer ( $73 \mathrm{~mm} \times 62 \mathrm{~mm}$ from PromoCan Ltd)". In future the most ideal product would be $a$ in a powdered form for reconstitution like infant formulae (or F75/100). It was not possible to return the tins for further reanalysis during the time of the trial since this was done prior to the analysis as a batch of 5. Overall the storage time was relatively short. 
Comment: The composition of the food product includes rapeseed oil. This does not seem to be used in the Ugandan diet. The justification for the use of this oil, particularly as it contains erucic acid is required.

Response: We understand that this was part of the Ugandan diet but it was the oil which had the appropriate palatability, constituents and certificate of analysis to comply with the current European standard. As shown in Table 3, the rapeseed oil used in this product was tested and observed to be $4 \mathrm{~g} / \mathrm{kg}$ which is far below acceptable levels of $50 \mathrm{~g} / \mathrm{kg}$ in the relevant European Commission Regulations.

Comment: There is no clarity on the type of legume used, that is, whether it was finally cowpea or chickpea. The manuscript published in the journal Cell Reports mentions cowpea. So which legume was used?

Response: We had studied prior to finalising the final ingredients for the feed the \% short chain fatty acid production of the cowpeas and chickpea available in the UK. Chickpeas were found to generate a higher degree of SCFA therefore this was included. We have made this clearer. Please also see initial clarification statement in this response - the reviewer has referred to a separate pilot study which had a different feed recipe and production process compared to the one being described here which was for use in a subsequent trial.

Comment: Shelf-life studies need to be done before the product is used for a study. If it has been done it needs to be reported. The manuscript should then be modified once this is completed.

Response: Please see our previous response to this question.

Competing Interests: none 